Катарина Митрићевић-Штепанек

Универзитет у Београду

Филолошки факултет

Катедра за славистику

k.mitricevic@fil.bg.ac.rs
УДК 811.162.3'367.622.23:811.163.41'367.622.23 https://doi.org/10.18485/slavistika.2020.24.2.7

оригинални научни рад примљено 07.07.2020.

прихваћено за штампу 18.09.2020.

\title{
АУГМЕНТАТИВИ У СРПСКОМ И ЧЕШКОМ ЈЕЗИКУ У ЧЕШКОМ НАЦИОНАЛНОМ КОРПУСУ
}

Рад се бави аугментативним изведеницама у српском и чешком језику ексцерпираним из Чешког националног корпуса (Český národní korpus) путем апликације Treq која обухвата преводне еквиваленте чешког и других језика засноване на подацима из паралелног корпуса InterCorp. У раду се прати њихова присутност у корпусу, анализира се њихова семантика и функција у српском језику и утврђују формални и семантички еквиваленти у чешком. Прецизирају се лексикографски еквиваленти и допуњава списак преводних еквивалената.

Кључне речи: аугментативи, српски језик, чешки језик, Чешки национални корпус, семантика, функција, еквиваленција.

The paper discusses augmentative derivatives in Serbian and Czech, collected from the Czech National Corpus (Český národní korpus) through the Treq application, which includes translation equivalents of Czech and other languages based on data from the InterCorp parallel corpus. Their presence in the corpus is monitored, their semantics and function in the Serbian language are analyzed and formal and semantic equivalents in Czech are determined. The lexicographic equivalents are specified and the list of translation equivalents is supplemented.

Keywords: augmentatives, Serbian language, Czech language, Czech National Corpus, semantics, function, equivalence.

1.

Као што је познато, аугментативи су модификациони деривати који означавају појам увећаних димензија, а ту семантику надстандардне величине често прати нијанса пејоративности. Они имају различит статус у српском и чешком језику, који проистиче из њиховог периферног положаја у чешком, те сматрамо да анализа еквиваленције има значај како за лексикографску, тако и за преводилачку праксу.

2.

Аугментативи у српском језику проучавани су у појединачним студијама са творбеног, семантичког и морфолошког становишта. На пример, истраживани су дублетни облици настали додавањем два и више различита суфикса на исту мотивну реч и обрађивана је проблематика њиховог бележења у двојезичним речницима (Бечева 2000), анализирана су њихова денотативна и конотативна значења и преиспитивана је прецизност термина ,речи субјективне оцене” (Вељковић-Станковић 2007), разграничавана је аугментативна и пејоративна компонента значења (Радуловић 1956), утврђивана њихова родовска граматичка припадност и морфолошка категорија броја (Чампар 1984), разматрано присуство и дефинисање у старијим и савременијим речницима српског језика (Кир- 
шова 1988). Пажња им је посвећена и у радовима који се тичу проучавања појединачних суфикса и творбено-семантичких категорија именица које се њима граде (Новокмет 2012; Пецо 1996). Детаљно су обрађивани у монографији (Јовановић 2010), у којој су са творбеног, семантичког и прагматичког аспекта истраживани механизми њиховог грађења, њихова семантичка структура и употреба у комуникацији. Аугментативни суфикси су у мањем или већем броју заступљени и у приручницима и граматикама српског језика, нпр. у Творби речи у савременом српском језику (Клајн 2003) и Савременом српскохрватском језику (Стевановић 1964). Аугментативи су такође били предмет контрастивног проучавања српског и словачког језика, у студији у којој је анализирано грађење, продуктивност суфикса и питања рода деноминалних аугментативних деривата (Макишова 2005).

У литератури није јединствен репертоар форманата који служе за деривацију, углавном због тога што се аутори разилазе по питању увршћивања датих изведеница у аугментативе, одн. у пејоративе. ${ }^{1}$ Рекли смо да аугментативи по дефиницији изражавају увећан појам, али да је код многих присутна и семантика пејоративности која код неких изведеница постаје примарна ${ }^{2}$, док мањи број деривата може изражавати и антонимично - хипокористично значење. Ипак, јединствено је мишљење о знатној продуктивности аугментативних суфикса -ина, -чина, -етина и -урина ${ }^{3}$, а као непродуктивни аугментативни, аугментативно-пејоративни или пак само пејоративни суфикси наводе се нпр. -ерина, -есина, -ешина, -екања, -уљина, -ушина, -уштина ${ }^{4}$, -енда ${ }^{5}$, -ерда ${ }^{6}$, -ескаpa, -иште, -уга ${ }^{7},-$-уа $^{8}$, -урда, -ускара/-ускера ${ }^{9}$, -уџа, -чага, -чуга итд.

${ }^{1}$ На пример, у приручнику Српскохрватски језик (Pесо et al. 1972: 37) пише да је аугментатив „изведена реч која означава нешто увећано” и да то значење често прати нијанса пејоративности, док је пејоратив дефинисан као „ружна, погрдна реч која се изводи додавањем посебних наставака" уз примере главурда, ножурда, ручурда, ножина, волина, ручетина, ручерина, зградурина, жентурина (1972: 265). Како видимо, као примери пејоратива наведене су само изведенице које се иначе сврставају у аугментативе, иако би овај низ могао бити проширен и другим дериватима који не спадају у категорију увећаница, као нпр. лудача, новинарчић и сл.

${ }^{2}$ То добро примећује В. Јовановић (2010: 111) у својој творбено-семантичкој анализи аугментатива, када каже да је граница између аугментатива и пејоратива нејасна и тешко одредива. Д. Вељковић-Станковић (2007: 389) наглашава да „поткатегорија 'велико’ имплицира наглашену одбојност” што је последица доживљавања великог као „опасност, девијацију, а то, логично, изазива одбојан став и активира читаву палету негативних емоција”.

${ }^{3}$ В. Јовановић $(2010: 102,104)$ сматра да је овај суфикс „са нешто изразитијом пејоративном компонентом значења у поређењу са аугментативима на -ина (-чина) и -етина”, а његову продуктивност приписује управо тој пејоративној компоненти значења.

${ }^{4}$ М. Стевановић (1964: 538) га назива пејоративним суфиксом.

${ }^{5}$ И. Клајн (2003: 76) га сматра пејоративним са шаљивим призвуком као у Србенда, попенда, паоренда. У првом и трећем примеру сматрамо да је присутан квантитет као саставни елемент значења, јер можемо рашчланити семантику деривата као велики Србин, велики naоp. Тиме би се суфикс -енда могао сврстати у аугментативно-пејоративне.

${ }^{6}$ Не наводи га В. Јовановић (2010).

${ }^{7}$ М. Стевановић (1964: 458) га назива пејоративним.

${ }^{8}$ Исто (1964: 509).

${ }^{9}$ И. Клајн (2003: 197) их назива пејоративним. 
У чешком језику аугментативни деривати обрађивани су углавном у граматикама, као што су Př́ruční mluvnice češtiny (Karlík et al. 1996), Velká akademická gramatika spisovné češtiny (Štícha et al. 2018), Mluvnice češtiny (Dokulil et al. 1986), и у приручницима, нпр. Slovník afixů užívaných v češtině (Šimandl 2017), а у појединачној студији су проучавани са типолошког становишта уз наглашавање да и аналитичку аугментацију, исто као и синтетичку, треба укључити у опис датих језичких јединица (Nekula 2010). У литератури се истиче да је њихова употреба у стандардној комуникацији веома ретка, а када су у питању творбени форманти, говори се првенствено о аугментативном суфиксу -isko. ${ }^{10}$ Остали суфикси као нпр. -izna, -ák, -an, -ajzna ${ }^{11}$, -anec ${ }^{12}$, -oun ${ }^{13}$, -our ${ }^{14}$, -as сматрају се у већини литературе аугментативно-пејоративним, или само пејоративним, понегде чак и само експресивним ${ }^{15}$, и истиче се да су у питању непродуктивни форманти за деривацију датих изведеница.

Неуједначеност како у српској тако и у чешкој литератури код одређивања творбених форманата који учествују у грађењу аугментатива, одн. пејоратива, отвара питање обимнијег творбено-семантичког истраживања у појединачним језицима, за које у нашем раду, који је конципиран као анализа еквиваленције у дата два језика, нема места. Због тога ми не доводимо у питање претходно наведена средства и њихове деривате, али за потребе ексцерпције и обраде грађе узимамо их према нашем избору и језичком осећању, а како би што боље илустровали дату проблематку.

У сваком случају запажа се знатна разлика у репертоару творбених средстава у дата два језика у корист српског, у ком је број суфикса скоро троструко већи.

3.

Грађа за наше истраживање ексцерпирана је из Чешког нациионалнг корпуса путем апликације Treq која обухвата преводне еквиваленте чешког и других језика засноване на подацима из паралелног корпуса InterCorp. ${ }^{16}$ Када је у

${ }^{10}$ Како наводи Velká akademická gramatika spisovné češtiny (2018: 599-603) на основу корпуса SYN2015, овај суфикс је заступљен са укупно 103 деривата, од којих већину чине оказионализми. Такође се наглашава да код неких од њих преовлађује или је присутан само емотиван став према појму, најчешће негативан, али да код једног броја деривата може бити и позитиван.

${ }^{11}$ Суфикс се не наводи у Mluvnice češtiny (1986).

${ }^{12}$ Суфикс се не наводи у Mluvnice češtiny (1986) ни у Přiruční mluvnice češtiny (1996).

${ }^{13}$ Суфикс се не наводи у Mluvnice češtiny (1986).

${ }^{14}$ Исто.

${ }^{15}$ Експресивним се у Slovník afixů uživaných v češtině (Šimandl 2017) сматрају суфикси -anec, -ajzna, -our, -as. Уколико бисмо говорили о појединачним дериватима, онда по нашем мишљењу неки од наведених, као нпр. chřipajzna (грипчина - наш превод), tlamajzna (губица, лабрға - наш превод), Němс̌оur (Немчина, Швабетина - ЧСР), јесу пејоративи, а одређене деривате могли бисмо назвати и аугментативно-пејоративним јер они значе и велики/јак грип, велика уста. Velká akademická gramatika spisovné češtiny (2018: 246) карактерише као експресиван суф. -as у деривату lotras, који наводи као стилску варијанту мотивне речи lotr.

${ }^{16}$ Доступно на https://www.korpus.cz/. 
питању српски језик, апликација омогућава претрагу у двема колекцијама, од којих једну представљају књижевна дела, а другу титлови. С обзиром на то да су еквиваленти у оквиру титлова углавном са трећим језиком као полазним и да богата грађа изискује другачији приступ, за потребе овог рада користили смо само прву наведену колекцију, док друга остаје за наредно истраживање. ${ }^{17}$

За полазни језик узели смо српски, а уносили смо деноминалне аугментативне деривате, као што смо рекли, по нашем избору из једнојезичних речника српског језика ${ }^{18}$, из поменуте претходне литературе, уз допуну списка сопственим примерима које у изворима нисмо пронашли. Речи се могу убацивати само у латиничном писму, а додавањем знака \% у резултатима се приказују сви постојећи морфолошки облици. Такође, узимали смо у обзир само директне преводе са српског на чешки језик и у вези с тим наша грађа потиче из књижевних дела српских аутора. ${ }^{19}$

Добијене деривате подвргли смо творбеној и семантичкој анализи у сваком од језика понаособ, а потом смо применили контрастивну анализу с циљем да утврдимо еквиваленте у чешком језику, како формалне, под којима подразумевамо аугментативне изведенице, тако и семантичке, у које убрајамо све остале начине преноса значења у циљни језик.

4.

Што се тиче творбене анализе изведеница, у грађи су према броју примера присутни суфикси: -ина (22 примера), -чина (10), -етина и -урина (по 7), -иште (3), -ура, -уштина и -ерина (по 2), -есина, -ештина, -ескара, -ерда, -уљина и -чага (по 1), одн.: -isko (5 примера), -izna (3), -ák (1). Како видимо, знатна је разлика не само у деривационим средствима у дата два језика уопште, него и у одабраној грађи, где је однос суфикса (14:3) а исто тако и однос самих изведеница $(61: 9)$ вишеструко у корист српског језика.

Када говоримо о творбеној основи, у српском језику су у већини случајева присутне мотивне речи које означавају лица (нпр. баба, будала, војник, газда, девојка, жена, јунак, мушкараи, офииир, човек, простак, момак, сељак, лажов, Шваба, циганка, дете, курва, пичка, лопов, поп), те предмете и појаве (ветар, вода, зграда, земља, кафана, киша, кућа, магла, пиштољ, пушка, рупа, торба, трава, кофер, шамар, ракија), затим делове тела (глава, језик, нос, очи, коса, брии, нога/ноге, рука/руке, тело), и најзад животиње (биво, во, пастув, кљусе, птица, пас, риба).

У чешком језику, дакако, чињеница да се ради о преводним еквивалентима условљава појављивање одређених деривата, али дајемо преглед мотивних речи, од којих су најбројније оне које означавају лица (bába/baba, voják, chlap)

\footnotetext{
${ }^{17}$ Могућности примене паралелних корпуса у контрастивним језичким истраживањима, њихове предности, недостатке и методолошке посебности истражује М. Мартинкова (Martinková 2014), а питањем разлика између преводног и непреводног чешког језика, а тиме и релевантности закључака изведених на основу анализе података из паралелних корпуса баве се Л. Хлумска и О. Рихтрова (Chlumská et al. 2014).

${ }^{18}$ Вид. одељак Извори.

${ }^{19}$ Вид. одељак Извори.
} 
и делове тела (hlava, oči, vlasy), а потом предмете (barák). Изведенице су, као и у српском, деноминалне.

Ако применимо семантичку анализу, надовезујући се на творбену, примећујемо такође да већина мотивних речи у српском језику има примарно неутрално значење, док су у мањем броју присутне лексеме са експресивном стилском обојеношћу, а то су деноминације особа, као погрдне речи будала, простак, Шваба, те вулгаризми пичка, курва.

У чешком језику такође преовлађују неутралне мотивне речи, док су неке лексеме маркиране као експресивне, или пак као општеразговорне (bába ${ }^{20}$, barák $^{21}$, chlap $\left.^{22}\right)$.

На основу несразмере у творбеним средствима за грађење аугментатива, као и на основу њихове продуктивности, те експресивне обојености, можемо закључити да се у функцији преводних еквивалената могу наћи у занемарљивом броју аугментативни деривати који спадају у тип формалне еквиваленције, што значи да се као претежни тип еквиваленције јавља семантичка еквиваленција.

Семантичке еквиваленте представљају мотивне речи у чешком које су еквивалентне са мотивним речима српских аугментатива, или пак неаугментативне изведенице. То могу бити стилски неутралне лексеме, употребљене у ноционалном значењу уколико су полисемичне, као нпр. блатиште - bláto; болештина - nеduh, петос, nakaženi; ветруштина - vichr; водурина - tekutina, voda; војничина - voják, земљетина/земљуштина - hlína, půda; јуначина hrdina, chlapík; кафанчина - kavárna; кућерина - di̊m; људескара - hromotluk, obr; маглуштина - mlha; месиште - таsо; брчине - kniry, пиштољчина - pistole; рупчага - kráter, jáma, díra; светина - dav, shluk, vřava, lidé, houf; телесина - tělo; ранчина - ranec; травуљина - tráva, travina; сељачина - primitiv; псина - pes; лажовчина - lhář; шамарчина - políček; пушчерина - puška; цчиганчура - cikánka; ритина - močál; лоповчина - zloděj. А присутне су и лексеме које су стилски карактерисане као грубе и пејоративне, нпр. будалина - pitomec; газдурина - pupkáč; главурда - kebule; девојчура - děvka; женетина - ženštinа; курвештина - соига; ножурда - hnáta; носина - frňák; официрчина - oficír; светина - li̊za, chátra, потом експресивне лексеме као газдурина - pracháč; јуначина - chlapák; мушкарчина - chlap; официрчина - lampasák; сељачина bagán, sprosták, или пак оне које су употребљене у варијантним експресивним и пејоративним значењима, а то су бабетина - bába/baba; биволчина - hovado; волина - vill; главурда - palice; женетина - ženská; nacтувчина - hřebec; рибетина - kос̌ka; ручерда - pracka; трбушина - mе̌ch.

${ }^{20}$ expr. baba i bába dospělá žena, zvl. vdaná; služebně $n$. jinak nadřizená žena; hanl. baba stará, ošklivá, nepř́ijemná, zlá, klevetivá žena (SSJČ). Дефиниција значења у ASSČ: 1. častěji bába, kolokv. stará žena; [...] 3. hanl. nepř́ijemná, zlá starši žena; 4. baba, kolokv. expr. žena, ženská, zejména pěkná nebo energická; 5. častěji bába, kolokv. expr. manželka, životni partner$k a$ итд.

${ }^{21}$ ob. bidná chalupa, staré sešlé stavení; chatrč (SSJČ). Дефиниција значења у ASSČ под бр. 1 kolokv. obytná stavba, di̊m.

${ }^{22}$ chlap 1. expr. muž, zprav. vyspělý a silný 2. ob. expr. muž vůbec (SSJČ). 
Формалне еквиваленте представљају следећи деривати: бабетина babizna; ветрина - větřisko; војничина - vojačisko; главурда - hlavizna; зградурина - barabizna; јуначина - chlapák; људина - chlapisko; очурде - očiska; коcypдa-vlasiska.

Поређења ради, наводимо и лексикографске еквиваленте из $S C H C \check{C}$. Највећи број деривата има описни, аналитички еквивалент, као нпр. ветрина - prudký vitr, водурина - velká voda, ošklivá voda; земљетина - pиstá zетё; земљурина pustá, neobdělávaná zете́; jезичина - velký jazyk; zlý, jedovatý jazyk; маглуштина - hustá mlha; pуnчаza - velká díra, velký otvor; торбетина - velká torba, taška; травуљина - velká vzrostlá tráva; рибетина - velká ryba, ošklivá ryba. ${ }^{23}$ Понегде се на другом месту налази и нека од раније поменутих неутралних или стилски маркираних лексема, нпр. главурда - velká hlava, palice; зградурина - velká, zchátralá budova, barák; љуудна - velký, silný muž, hromotluk, obr; pучерда u ручетина - velká ruka, hnáta; јуначина - velký hrdina, silák. Постоји неколико деривата који нису присутни у речнику, али јесу њихове варијанте грађене од исте мотивне речи другим суфиксом: курвештина - / : курветина - velká kurva; ножурда - / : ножурина - velká noha, hnáta; ножекањa - / : ножина - velký, ohromný nůž, међу којима је у само једном случају еквивалент и аугментатив - очурде - / : очетине - velké oči, očiska. За мањи број деривата еквивалент је неутрална или стилски маркирана лексема која није прецизирана атрибутом или на неки други начин: блатиште - bahnisko, bahništęe4; ветруштина - vichr, vichřice; војничина - voják; женетина - ženská, ženština; кишурина - liják, lijavec, slejvák; мешина - те̌ch, panděro; простачина - hrubec, sprosták; шамарчина - facka; ракичина - kořala.

Аугментативни деривати су присутни, било самостално или уз друге еквиваленте, у следећим примерима: бабетина - baba, babizna, babice; девојчура holka, děvčisko, silná, statná dívka ${ }^{25}$; кућерина - velký, obrovský di̊m; expr. barabiznа; момчина - chlap, chlapisko; носина - velký nos, nosisko; ncuна - psisko, velký pes; птичурина - ptačisko, velký pták; сељачина - chám, chřupan, sedlačisko statné postavy; људескара - hromotluk, chlap jako hora, chlapisko, obr; комадина - velký kus, kusanec. ${ }^{26}$

Узимајући у обзир избор грађе која је великим делом условљена обимом речника, видимо да се ради о малом броју аугментативних изведеница које се појављују у функцији лексикографских еквивалената. Исто тако, чини нам се

${ }^{23}$ У нашој грађи дериват је употребљен у метафоричном значењу веома лепа, згодна девојка/ жена, који, разумљиво, речником није обухваћен.

${ }^{24} \mathrm{У}$ формирању аугментативног деривата у српском језику учествује и акценат, па је тако у РСJ дато блӓтйште место где је некад било језеро, блатьаво, мочварно земљиште, а блаттйште аугм. од блато. На основу наведених лексема у речнику видимо да се ради само о преводним еквивалентима првог деривата.

${ }^{25}$ Еквивалент наведен у SCHČR под бр. 2 silná, statná dívka присутан је у РMC снажна девојка, али сматрамо да је данас доминантно пејоративно значење, како је уосталом наведено у РСJ 1 аугм. и пеј. од девојка; 2 морално искварена девојка, дроља.

${ }^{26}$ У речнику Nový encyklopedický slovník češtiny (Karlík et al. 2016: 137) овај пример наводи се у оквиру спорадичног грађења аугментативних деривата суфиксом -anec. 
да известан број и не одговара семантичком садржају аугментатива у српском језику, јер је део њих у речницима и у новијој литератури дефинисан као експресивна лексема, а не као аугментатив. ${ }^{27}$

5 .

Када говоримо о еквиваленцији у контексту, употреба формалних еквивалената је, сходно њиховом занемарљивом броју и фреквенцији у чешком језику, у великој мери додатно условљена окружењем.

Тако су нпр. у преводу једног истог књижевног дела употребљени у различитим контекстима аугментативна изведеница и мотивна реч, у зависности од функције аугментатива у исказу:

(1a) Ćuti tu, babetino! zalaja zubati Mrkoje i još grublje je odgurnu. (МБ)

(1б) Mlč, ty babizno, štěkl zubatý Mrkoje a odstrčil ji ještě hruběji.

(2a) Zgurio si se kao neka babetina. (МБ)

(2б) Schoulil ses jako nějaká stará bába.

Како видимо у примеру (1a/б), у функцији упућивања погрде послужио је аугментативни дериват, док је мотивна реч употребљена у контексту у ком није неопходна лексема са тако јаком експресивном обојеношћу (прим. 2a/б).

Аугментатив се избегава и уколико у полазном језику постоји одређени елемент којим се његова семантика прецизира, а најчешће се то чини конструкцијом атрибут + мотивна реч:

(3a) Ova vetrina samo bolest raznosi, vojvodo. (ДЋ)

(36) Tohle větřisko jen roznáší nemoc, pane vojvodo.

(4a) Šuma huči, valja se ledena vetruština i magla. (ДЋ)

(46) Les hučí, všude kolem fičí ledový vichr a valí se mlha.

(5a) $[. .$.$] mokra vetruština zbaci mu šajkaču sa smršale, smanjene glave. (ДЋ)$

(5б) Mokrý vichr mu strhl čapku z vyhublé, scvrklé hlavy.

Од аугментатива као неуобичајеног елемента у чешким исказима одустаје се посебно у примерима када дериват у српском нема пејоративно значење:

(6a) Njegov brat Vuk, koga je neizmerno voleo dok beše dete, jer je bio jači od njega i jer je znao da govori ciganski, bio mu je mio i posle, kao amanet očev i kao luda, pusta vojničina koja se samo njega bojala. (МЦ)

(6б) Bratr Vuk, kterého v dětství nesmírně miloval, protože byl silnější než on a protože uměl mluvit cikánsky, byl mu milý i později, když mu ho otec svěřil do péče, i jako bláhové nevázané vojačisko, které se bálo jenom jeho.

(7a) Znaš li ti da sam ja svoju košulju cepala da previjem vojnicima rane? Da sam te nesrećne vojničine na leđima iznosila sa bojišta, pa mi krv iz njihovih rana probije

${ }^{27}$ Нпр. неки од деривата са суфиксом -isko у речнику Slovník afixů uživaných v češtině (Šimandl 2017) карактерисани су као експресивни уз појашњење да се „původní augmentativní př́znak sufixu -isko, pocit’ovaný v moravských nářečích (chlapisko ,silný chlap“; dračisko ,velký drak $\left.^{c}\right)[\ldots]$ během vývoje přehodnocoval; dnes má augmentativní či pejorativní příznak jen část těchto derivátů (chlapisko, psisko, ušisko) [...]”. Исто тако нпр. sedlačisko у SSJČ expr. sedlák. 
kecelju, bluzu i košulju, da mi budu mokra i krsta i bedra. (ДЋ)

(7б) Víš, že jsem roztrhala vlastní košili, abych vojákům mohla obvázat rány? Že jsem ty nešt’astné vojáky vynášela na zádech $\mathrm{z}$ bojiště a krev z jejich ran mi prosákla zástěrou, blůzou i košilí a měla jsem mokrý křriž a bedra.

У примеру (7a/б) присутна је семантика саосећања и сажаљења која представља негацију особине изражене аугментативом - снажан војник.

Слично је и у примеру (8a/б) у ком изостаје негативна евалуација:

(8a) Kakav si rogljast i glasan, imaš te brčine i očurde, ličiš na pravu čovečinu. (ДЋ)

(8б) Jak jseš takovej střapatej a halasnej a máš ty kníry a očiska, vypadáš jako opravdickej chlap.

У исказу оригинала су аугментативи употребљени ради наглашавања позитивне евалуације. Мада изведеница човечина има еквивалент - chlapisko, нагомилавање аугментативних деривата у непосредној близини било би пренаглашено, па он стога није ни употребљен.

Понекад је контекстом наметнута употреба аугментатива, као нпр. када исказ оригинала садржи поређење.

Оно може бити у функцији истицања негативног пола, поређењем са позитивним, као нпр.:

(9a) Babetina mu se pojavi na mesto prve ljubavi, praznina na mesto gradova, $u$ kojima je živeo, trgovao, ili kopao jarkove, pucao i tukao ljude. (МЦ)

(9б) Místo první lásky se mu zjevila babizna, bezedná prázdnota místo pevností a měst, v nichž kdysi žil, obchodoval nebo kopal zákopy, stř́lel a mlátil lidi.

Или се пак поређењем са опозитном лексемом само наглашава одређени квантитет/квалитет на скали, било према позитивном или према негативном полу:

(10a) Ono, ovakvo, usukano, pogureno, bezbrko, vetar može da ga oduva, sada komanduje ljudima, ljudinama. (ДЋ)

(10б) Takovýhle všelijaký, vyzáblý, shrbený, bez knírů, vítr ho může odfouknout, a velí chlapům, chlapiskům.

Такође, исказ може да садржи набрајање истих појмова обухваћених семантиком увећаног квантитета/квалитета:

(11a) Znala mu ime, a u sebi, i kad je ne čuje, nije ga zvala Brka, kako su ga svi zvali, već Brkonja, kao što je i za njegove oči govorila da su očurde, za kosu - kosurda, za glavu - glavurda. (ДЋ)

(11б) Věděla, jak se jmenuje, ale v duchu, a když ji neslyšel, mu neříkala Knír, jak mu říkali všichni, ale Kníroun, stejně jako o jeho očích říkala, že jsou to očiska, o vlasech - vlasiska, o hlavě - hlavizna.

Што се тиче семантичких еквивалената, уколико у чешком језику не постоји аугментативни дериват, користи се мотивна реч према мотивираној у српском. Најчешће се употребљавају конструкције са атрибутом који прецизира семантику аугментатива у српском језику, као нпр. velký, vysoký, hrozitánský (cmpaшан, велики, огроман), těžký код семантике квантитета, или zatracený (проклет) код семантике квалитета, а затим и друге сличне конструкције: 
(12a) Magluština pritisla varošicu, zna: krcatu izbeglicama, komorom, ranjenicima. (ДЋ)

(126) Těžká mlha zalehla městečko, ví: je přeplněné běženci, trénem, raněnými.

(13a) Beše neka magluština mnogo gora od one kad ti deda i ja lovimo divlje guske po zaleđenoj Moravi. (ДЋ)

(136) Byla nějaká hrozitánská mlha, o moc horší než ta, když jsme ty, dědo, a já lovili divoké husy po zamrzlé Moravě.

(14a) Na licima koja dobro zna izrasle neke brčine, glasovi lekara i bolničara postali preteći, svi viču. (ДЋ)

(146) Na dobře známých obličejích narostly nějaké veliké kníry, hlasy lékařù a ošetřovatelů dostaly výhrůžný tón, všichni křičí.

(15a) Jer u ovoj kućerini sve je zaraženo poganim, naopakim bludom, drvo i kamen i poslednja krpa. (ИА)

(156) Protože v tomhle zatraceném domě je všecko nakažené hnusnou, zvrácenou nemravností, dřevo, kámen i ten poslední hadr.

(16a) U svanuće, kad su krenuli u Boljkovce, činilo mu se da će se kuće raspasti od vodurine, bregovi kao krtičnjaci krenuti ka dolini, putevi se izmešati s vrzinama i oteći u Kolubaru i Ljig. (ДЋ)

(16б) Za rozbřesku, když vyrazili do Boljkovců, měl pocit, že se chalupy rozsypou z těch př́valů ${ }^{28}$ vody, svahy sjedou jako krtince do údolí, cesty se pomíchají s houštinami a odtečou do Kolubary a Ljigu.

Понекад су већ у тексту оригинала присутни елементи који прецизирају значење аугментатива, као нпр.:

(17a) Evo vam ova prokleta puščetina, a ja odoh kući. (ДЋ)

(17б) Nate tadyhle tu zatracenou flintu a já jdu domů.

(18a) U visokoj, gustoj travuljini, oko nje, beše zavetrina, pred njenim vratima tikve se žutile. (МЦ)

(18б) Ve vysoké trávě kolem chatrče bylo závětríi, před jejími dveřmi žloutly dýně.

У примерима (17a) и (18а) ради се о елементима који додатно изражавају увећан квантитет (висок, густ) или квалитет (проклет) појма означеног аугментативом, што у чешком језику (прим. $17 б$ и 18б), употребом мотивне речи, изостаје. Међутим, свеукупни изостанак или ниска фреквенција датих средстава у чешком указују на то да у многим примерима није могуће нити пожељно нагомилавање елемената, јер у супротном исказ не би био у духу језика.

Преводиоци такође прибегавају замени елемената у контексту или употреби оних са јачом стилском обојеношћу од елемената у полазном језику:

(19a) Ishrana je sumnjiva pa se čovek pita kako taj narod koji isključivo jede mesište i prilično pije još uvek fizički opstaje. (ДВ)

${ }^{28}$ přval - буjuй. Уместо аугментатива послужила је синтагма бујице воде која такође изражава значење велика, снажна вода. 
(19б) Potrava má podezřelou hodnotu a člověk si říká, jak ten lid, který výlučně hltá ${ }^{9}$ maso a hodně pije, pořád ještě fyzicky přetrvává.

(20a) Tu će, psinu švapsku, u svinjsku balegu prvaka Beča! (ДЋ)

(20б) Tady oddělá to rakouské prase, do prasečího lejna s mistrem Vídně!

(21a) Ako siromah ne truli na Suvoboru sada ga prema Beču jaše neki Švaburina general. (ДЋ)

(21б) Jestli ubožák nehnije na Suvoboru, tak ted’ na něm k Vídni rajtuje nějaký rakušácký ${ }^{30}$ generál.

(22a) Kapetan Antonovič, u svom neuredno napisanom izveštaju, naročito mu naglašavaše: da je profus, koji predvodi četu dragona, jedna pijana bivolčina kirasirska. (МЦ)

(226) Kapitán Antonovič ve svém ledabyle sepsaném hlášení zdůrazňoval, že profous, který velí rotě dragounů, je ožralé31 kyrysnické hovado.

(23a) Ma beži od mene, vojničino! Švabe čekaj, nemoj za suknjom da juriš, psino. (ДЋ)

(23б) Táhni ode mě, mizero ${ }^{32}$ vojenská! Čekej na Rakušáky a nehoň se za sukněmi, pacholku!

(24a) Kada ga već potrefilo, što ga ne probuši malo levo i naviše pa da mogu da se nalokam rakičine i pred opštinom viknem Prerovcima: „Dva su mi poginula!“ (ДЋ)

(24б) Když už ho to potrefilo, proč ho to neprovrtalo trošku víc vlevo a nahoře, abych si moh ožrat dršku ${ }^{33}$ a před obecním úřadem houknout na Prerovany: „Dva mi padli!“‘

У одређеним контекстима у којима се исказује негативан став говорника према појму врло добро врши функцију семантичког еквивалента стилски маркирана лексема која, како смо већ поменули, може бити експресивна или пејоративна (евент. хипокористична), или може припадати општеразговорном слоју чешког језика:

(25a) Ženetino krezuba! otseče žena i pođe. (МБ)

(25б) Babo kolozubá! odsekla žena a šla dál.

(26a) Šabačka gazdurina. Kad su mu gospođe onako debele, debela mu je i kasa. (ДЋ)

\footnotetext{
${ }^{29}$ hltat гутати; јести халапљиво (ЧСР).
}

${ }^{30} \mathrm{C}$ обзиром на то да се у чешком језику пејоратив Němс̌оur - Шваба не односи на особу аустријске националности, употребљен је придев од мотивне речи Rakušák, погрдног значења у односу на неутралну Rakušan. Придев неутралног значења гласи rakouský.

${ }^{31}$ ožralý вулг. нашљькан, наљьоскан, јако пијан (ЧСР). Ožralé hovado бисмо превели као нашььокано говедо.

32 mizera разг. погрд. бедник, хуља, ништарија (ЧСР). Тако би се mizera vojenská могло превести као беда од војника. Пејоративно значење је појачано употребом облика придева у женском роду који стоји уз именицу мушког рода. О томе вид. и нап. 50.

${ }^{33}$ drštka, držka, drška разг. вулг. юушка, губииа, лабрња (људска); оžrat sе вулг. нашљокати ce, наљоскати се (ЧСР). Израз ožrat si dršku, настао комбинацијом две вулгарне лексеме, има још јачу негативну конотацију. 
(26б) Nějaký pracháč ${ }^{34}$ ze Šabce. Když má takhle naditý ženský, bude mít taky naditou prkenici.

(27a) Jed i čemer spopali gazdurine. Odoše vam nadničari i sluge. Opusteće vam njive i vinogradi, nema ko livade da vam pokosi. Vama je rat, Katići. Sad smo ravni. (ДЋ)

(27б) Hněv a hoře trhly na pupkáče ${ }^{35}$. Odejdou vám nádeníci a čeledíni. Zpustnou vám vinice i pole, nebude, kdo by vám pokosil louky. To pro vás vypukla válka, Katićové. Ted' jsme na tom stejně, ted' jsme si rovni.

(28a) Sa izmahnutom močugom čeka da mu priđu, traži oficira među njima, da mu razbije švapsku glavurdu. (ДЋ)

(28б) Se zvednutým klackem čeká, až přijdou k němu, hledá mezi nimi důstojníka, aby mu rozrazil jeho rakouskou palici. ${ }^{36}$

(29a) Da obiđe onog majora Stankovića, tu tipičnu militarističku glavurdu? (ДЋ)

(296) Má se jít podívat na toho majora Stankoviće, na tu typickou militaristickou palici?

(30a) Na mesnatim glavudžama zablistaše uvlakački osmesi prepuni prikrivenog iščekivanja. (3h)

(30б) Na masitejch kebulích ${ }^{37}$ zazářily nohsledský úsměvy plný skrytýho očekávání.

(31a) Ljudi su sebičniji od kurjaka. Ženetine naročito. (ДЋ)

(316) Lidé jsou sobečtější než vlci, než zvěř. A ženskéé 38 zvlášt'.

(32a) Ponadao sam se da će nas odvesti negde gde se toče ljuta pića za ljute muškarčine. (3h)

(32б) Doufal jsem, že nás zaveze někam, kde se nalejvá tvrdej chlast pro tvrdý chlapy. ${ }^{39}$

(33a) Tako, opruži te tvoje masne i debele nožurde i dremaj. (МБ)

(336) No tak, natáhni si ty svoje masité a tlusté hnáty ${ }^{40}$ a podřimuj.

(34a) Drugo je još neobičnije: brkato, čupavo, s nosinom sovuljage. (МБ)

(346) Druhé je ještě zvláštnější: kníraté, střapaté, s frňákem ${ }^{41}$ výra.

(35a) A u sebi ne može da prežali tu ručerdu sa šakom kao ašovom, koja je

${ }^{34}$ pracháč hanl. bohatý člověk, boháč (SNČ) - nарајлија, богатун (наш превод).

${ }^{35}$ pupkáč hanl. bohatec (SSJČ) - nарајлија, нафатирани (наш превод). У ЧСP само разг. експр. трбоња, пупавач.

${ }^{36}$ palice expr. hlava (SSJČ) - тиква, глава (ЧСP).

${ }^{37}$ kebule zhrub. hlava (SSJČ) - вулг. тиква, тинтара (ЧСР).

38 ženská об. погрд. женска (ЧСР).

${ }^{39}$ chlap експр. мушкараи, момак, момчина (ЧСР). У неким контекстима може се превести као фрајер, тип.

${ }^{40}$ hnáty вулг. краци (руке и ноге об. комчате) (ЧСР).

${ }^{41}$ frňák вулг. нос, юуика (ЧСР). 
mogla pune kante kukuruza da podigne, konja u trku da zaustavi, skelu na Moravi da povuče... (ДЋ)

(35б) V duchu však nemůže oželet tu pracku ${ }^{42} \mathrm{~s}$ dlaní jako rýč, která dokázala zvedat plné koše kukuřice, zastavit koně v letu, odtáhnout prám na Moravě...

(36a) Ne podvaljuj, seljačino. (ДЋ)

(36б) Nešid' mě, bagáne ${ }^{43}$ jeden.

(37a) Nešto što su oglodale psine, te koje po svu noć reže i zalajavaju ispod prozora. (ДЋ)

(376) Něco, co už okousali hafani ${ }^{44}$, ti, co celou noc vrčí a štěkají pod okny.

(38a) E, nećete ga, prostačine! (ДЋ)

(386) Starou belu, sprost'áci ${ }^{45}$ !

(39a) „Čuvaj novac za dobrovoljni prilog“, prilepio sam mu šamarčinu. (3Ћ)

(396) „Prachy si schovej na charitu,“ vlepil jsem mu facku.

(40a) Zamisli samo da je spazi neka oficirčina. (ДЋ)

(40б) Ale přsedstav si jen, že by si jí všimnul ňákej oficír!

У примеру (40a/б) експресивност и евалуативност деривата у српском изражена је не само лексемом која припада општеразговорном чешком језику и често се употребљава у погрдном значењу, већ и обликом придева који уз њу стоји и који такође припада некњижевном слоју чешког језика. Тако দ̌ákej (књиж. nějaký) можемо између осталог превести као некакав, тамо неки/некакав.

У вези са употребом стилски маркираних деривата наводимо пример у ком су употребљени вулгаризми:

(41a) Ali ti treba pičica. Pička. Pičketina. (3h)

(41б) Ale potřebuješ pičku. Kundičku. Kundu.

У примерима (41a/б) трочлани низ деминутив - мотивна реч - аугментатив, у недостатку аугментативног деривата у чешком језику надокнађен је употребом две синонимичне лексеме ${ }^{46}$, од којих се друга, која је у функцији аугментативног еквивалента (kunda), сматра изразито вулгарном.

Стилски неутрална лексема такође може бити употребљена као еквивалент, ако је њен семантички садржај одговарајући, као нпр. када је у питању аугментатив са позитивном евалуацијом:

(42a) Kapetan Popović je komandant vašeg specijalnog bataljona - pokazao je rukom na kapetana ljudeskaru. (ДЋ)

\footnotetext{
${ }^{42}$ pracka експр. об. погрд. шапа, рука (об. велика) (ЧСР).

${ }^{43}$ bagán разг. експр. сељачина, простак (ЧСР).

44 hafan експр. (велики) пас, псина (крупне пасмине) (ЧСР). Дериват је настао од ономатопеје лавежа $h a f-a b, a b$.

${ }^{45}$ sprosták разг. експр. простак, простачина (ЧСР).

${ }^{46}$ pička исто и kunda vulg. ženské přirození, vulva (SNČ).
} 
(426) Kapitán Popović je velitelem vašeho speciálního praporu - ukázal rukou na kapitána, kníratého hromotluka ${ }^{47}$.

(43a) Možda bih sinoć pobegao iz rova da nisam u istoj četi sa slugom moga dede Aleksom Dačićem. Jednom ljudinom i junakom kakvog u puku nema. (ДЋ)

(436) Třeba bych dnes v noci utekl ze zákopu, kdybych nebyl ve stejné rotě s čeledínem mého dědy Aleksou Dačićem. S hromotlukem a hrdinou, jaký se už v pluku nenajde.

(44a) Nije više bilo muškobanjastih žena, ni onih ljudeskara i kepeca što su se uz trešnju bacali kamenicama i drvljem. (МБ)

(446) Nikde už nebylo vidět ani ženy mužatky ani ty obry a trpaslíky, co do koruny třešně házeli kamení a klacky.

У примеру (44a/б) ради се о поређењу са антонимичном лексемом (људескара : кепец) којим се наглашава семантика квантитета, а употребом лексеме $o b r$ $(\partial u в$, горостас, колос) у чешком језику сачувана је конфронтација и без присуства аугментатива (obr: trpaslik).

У преводу се понекад појављује и устаљени израз, чије је значење еквивалентно аугментативном деривату:

(45a) Čini mu se još da ga, dok se vuče pored tuđih plotova, prati besni Muharem: jezdi na crnom ždrepcu, jezdi namrgođena momčina nabranih obrva, i nosi kao koplje nožinu od dva metra, i hoće na nj da ga nabode. (МБ)

(45б) Jak se tak vleče podél cizích plotů, zdá se mu, že ho sleduje zuřivý Muharem: jede na černém hřebci, jede zachmuřený s nasupeným obočím chlap jako hora ${ }^{48}$ a jako kopí drží dvoumetrový nůž a chce ho na něj nabodnout.

(46a) Taj vaš Muharem jezičinu ima, a ne jezik! (МБ)

(46б) Ten váš Muharem má jazyk jako břitvu ${ }^{49}$.

(47a) A zar se, Vukajlo, lažovčino, nismo noćas dogovorili da ko se prvi probudi, budi drugog? (ДЋ)

(47б) A nedomluvili jsme se, Vukajlo, ty lháři prolhaná ${ }^{50}$, že kdo se probudí první, vzbudí druhýho?

У мноштву веома добрих решења, потеклих из пера врсних преводилаца, Душана Карпатског, Миладе Недвједове, Јиржија Фидлера, Ане Адамовић и Јана Долежала, наишли смо на неке случајеве код којих сматрамо да би семантика аугментативних деривата могла бити прецизније пренета у чешки језик.

У појединим примерима нам се чини да и поред окружења мотивна реч не одговара експресивности и субјективној оцени аугментатива и целокупног исказа у српском језику:

\footnotetext{
${ }^{47}$ hromotluk грмаль (ЧСР).

${ }^{48}$ chlap jako hora sудина (ЧСР).

${ }^{49}$ mit jazyk jako britvu uмати оштар језик (ЧСР).

${ }^{50}$ Ословљавање ty lháŕi prolhaná које можемо превести као лажовчино (једна) лажљива представља увреду упућену саговорнику која се, поред семантике синтагме и понављајуће особине у главном и зависном члану, још више наглашава употребом облика атрибута у женском роду уз именицу мушког рода. Слично нпр. и у lenochu líná-ленштино (једна) лења.
} 
водурина : voda - kalná, špinavá voda

(48a) Oblačina smotala visove oko sela što se u strahu i bedi rasulo po stranama i potocima, pod kišom i muklom topovskom grmljavinom sabilo u kaljavu rupčagu. Pred njim, jarkom, s brda teče rujna vodurina, kakvu do sada nije video. (ДЋ)

(486) Mračna zahalila vrchy kolem vsi, jež se v strachu a bídě rozptýlila po stráních a potocích a $\mathrm{v}$ dešti a dutém dělostřeleckém hřmění se schoulila do blátivé díry. Před ním ve škarpě teče z kopce nějaká červená voda, jakou ještě nikdy neviděl.

У примеру (48a) аугментативом је изражен емоционални став јунака романа према води - одвратна прљава вода, који у преводу недостаје, па би по нашем мишљењу било потребно допунити мотивну реч атрибутом, нпр. kalná, špinavá voda.

волина : viol- řvát jako tur; hovado/dobytek

(49a) „Ne riči, volino“, prekinuh ga pesnicom u teme, ,da ne rikneš zauvek.” (3Ћ)

(496) „Neřvi, vole,“ přerušil jsem ho pěstí do hlavy, ,abys tady nezařval navěky.“

У исказу (49а) лексема волина употребљена је као инвектив и погрдна је, а у комуникативној ситуацији представља остварен говорни чин увреде. Лексема vi̊l у чешком данас спада у слабије увреде, јер је у разговорном језику њена употреба померена ка речцама и узвицима или поштапалицама, ${ }^{51}$ те у контексту (49б) по нашем мишљењу не уноси одговарајући степен пејоративне нијансе значења. С обзиром на то да постоји фразем řvát jako tur, сматрамо да би у овој ситуацији прецизнији превод био Neřvi jako tur!, или евент. Neřvi, ty hovado/dobytku!, где се наведене лексеме у метафоричном значењу односе на сирову или глупу особу и представљају псовку.

јуначина : hrdina - velký hrdina

(50a) Kosa mu je padala na debeo, pljosnat nos, i takav, bez visokog klobuka, gologlav, ne samo da više nije izgledao junačina, nego se činio gotov na smrt. (МЦ)

(50б) Vlasy mu padaly na široký plochý nos a bez svého vysokého klobouku, jen tak holohlavý, nejenže už nevyhlížel jako hrdina, ale vypadal spíše jako by měl smrt na jazyku.

Негирање увећаног квалитета у исказу оригинала (не само да вище није изгледао јуначина) није сачувано употребом мотивне речи у преводу (прим. $50 \mathrm{a} / б)$. По нашем мишљењу би више одговарала конструкција са атрибутом, нпр. velký hrdina.

ииганчура : cikánka mizerná - cigánka (jedna)

(51a) Cigančuro, šta će tebi medalje? (ДЋ)

(51б) Cikánko mizerná, $\mathrm{k}$ čemu ti budou medaile?

Изразито омаловажавање српским аугментативом у исказу (51a)није по нашем мишљењу присутно у преводу, те сматрамо да се семантика пејоративности у овом случају може боље изразити лексемом cigán која се свакако налази више на

${ }^{51}$ О лексеми vi̊l и њеним значењима, морфолошким карактеристикама и прагматичкој употреби писао је нпр. Ф. Чермак (Čermák 2001). 
скали пејоративности. У конкретном случају би тако семантички приближније ословљавање у датом контексту било cigánko jedna.

кљусина : obrovská herka - herka

(52a) Umesto takvog plena i takvih zarobljenika, njegov eskadron redovno zarobljava gomile kaljavih i bednih pešaka, svakojaku komoru s nekakvim mršavim kljusinama koje ne mogu da se iščupaju iz blata, pa u jarcima stoje nepomične ili kao goveda leže u poleđenim barama. (ДЋ)

(526) Místo takovéto kořisti a takovýchto zajatců jeho eskadrona pravidelně zajímá zástupy zablácených a ubohých pěšáků, všelijaký trén s nějakými obrovskými vyzáblými herkami, které nejsou $\mathrm{s}$ to se vydrápat $\mathrm{z}$ bláta, a tak stojí nehybně ve škarpách anebo leží jako dobytek na zamrzlých loužích.

У жељи за што прецизнијим преносом текста оригинала, а у недостатку формалног еквивалента, употребљена је у преводу (52б) конструкција атрибут + мотивна реч (obrovské herky), али нам се она чини неодговарајућом у поређењу са семантиком аугментатива у српском. Лексема кљусина изражава квалитет, а не квантитет појма означеног аугментативом, дакле, не ради се о великом кљусету, него о измрцвареном и неупотребљивом коњу, на шта указује не само дериват, него и цео исказ, те је по нашем мишљењу сувишан атрибут obrovský (огроман), који чак изражава семантику већи од великог.

птичурина : obluda ptačí - zatracený pták

(53a) Sad će noć pa će i ptičurine da se smire, Visočanstvo. (ДЋ)

(536) Brzy bude noc, a tak se i ty obludy ${ }^{52}$ ptačí uklidní, Výsosti.

Понекад је тешко одредити да ли се ради о денотативном или конотативном значењу, да ли је у питању квантитет или квалитет (прим. 53а/б). По нашем мишљењу аугментатив је у тексту оригинала употребљен у негативној евалуацији, а не у изражавању увећаног појма. Тако превод синтагмом obludy ptačí (грдосије од птиц̧а) није адекватан, те би одговарала нпр. конструкција са атрибутом zatracení ptáci (проклете птице).

кафанчина : kavárna - рог̆ádná/ř́dná hospoda

(54a) Идемо у механу. Кафанчину. Српску кафанчину. Једину часну установу наше слободе. (ДЋ)

(546) Pojd’me do hospody. Do kavárny. Srbské kavárny. Jediné počestné instituce naší svobody.

За аугментатив кафанчина еквивалент kavárna није одговарајући. С обзиром на то да се у ближем контексту налазе две лексеме које имају исто или приближно значење, прва од њих - механа, може се превести као hostinec, док би се друга, изражена аугментативом, могла превести као hospoda. С обзиром на то да контекст указује на позитивну евалуацију, уз лексему би могао да стоји атрибут који прецизира семантику и присуство веће количине особине, па би превод гласио: Pojd'me do hostince. Do hospody. Pořádné/ř́dné srbské hospody.

И на крају наводимо један интересантан пример превода, у ком се за аугментатив у српском језику у функцији еквивалента налази деминутив у чешком језику:

\footnotetext{
${ }^{52}$ obluda експр. грдосија, неман (ЧСР).
} 


\section{јуначина: junáček}

(55a) Junačino moja slatka... Medaljama, zlatnim Obilićima imaš ti da se igraš. Zdipiće za tebe tvoja majka. Pridrži mi ga, molim te, da operem pelene. (ДЋ)

(556) Ty můj junáčku malej... Ty si budeš hrát s medailema, se Zlatejma Obilićema, to ti povídám. Matka je pro tebe šlohne. Podrž mi ho, prosím tě, at' můžu vyprat plíny.

Обраћање мушком детету употребом аугментатива, овде са позитивном субјективном оценом, представља формулу у тешким временима која одсликава стање свести српске мајке, чије новорођенче треба да постане велики јунак. Та функција не може бити сачувана у тексту превода јер би имала непримерену конотацију, с обзиром на преовлађујућу тенденцију чешких говорника да користе деминутивне изведенице при обраћању младим бићима, као уосталом и у бројним другим функцијама. Осим тога уз деминутивну изведеницу стоји и атрибут malý којим се додатно наглашава маленост и драгост и чија употреба у чешком језику није плеонастична. Наведени однос еквиваленције у реченицама (55a) и (55б) добро илуструје пример различите слике света српских и чешких говорника.

6.

На основу претходног можемо извести више закључака.

Апликација Treq Чешког нащионалног корпуса представља релевантан извор богате грађе за проучавање међујезичке еквиваленције, а на примеру јединица које су у језицима различито заступљене чини важну карику у утврђивању процеса дефинисања и преноса њиховог значења из полазног у циљни језик. Укључивање података из корпуса омогућава прецизирање семантике и функција истраживаних елемената у полазном језику и проширивање списка преводних еквивалената у циљном језику.

Аугментативни деривати у српском језику присутни су већином у делима која обрађују војну, ратну и сличну тематику и уопште тешке, мучне и сурове прилике. Ауторима, који су узгред буди речено сви мушког пола, служе за стилизацију превасходно мушких ликова, истичући њихову сировост, грубост, или пак неопходну и пожељну снагу и моћ у датом миљеу. Уколико се односе на женске ликове, што је вишеструко ређе, карактеришу их као мушкобањасте, старе, незграпне или неморалне.

Већ на основу поређења репертоара суфикса за грађење аугментатива и њихове продуктивности запажају се знатне разлике између српских и чешких језичких средстава и њиховог семантичког потенцијала да синтетички изразе денотативно значење аугментатива - увећане димензије појма, као и да та компонента значења буде у саставу конотативног значења пејоративности, а све у корист српског језика.

Лексикографски еквиваленти у чешком језику су у највећем броју аналитички, посебно када је у питању семантика квантитета, али уколико је у питању семантика квалитета, такви еквиваленти не уносе пејоративну нијансу значења и због тога је неопходно да у функцији преводних еквивалената буду присутне лексеме које су стилски маркиране, као експресивне, пејоративне, вулгарне и слично. 
Што се тиче преводних еквивалената, можемо рећи да се аугментативи не употребљавају аутоматски у циљном језику, чак и када постоје, јер њихова изразита експресивна обојеност и преовлађујућа пејоративна нијанса значења делују пренаглашено у чешком језику. Уместо аугментатива, посеже се за другачијим средствима која су примеренија, као што су речи општеразговорног чешког језика (колоквијалне), као и разне друге стилски маркиране речи -експресивне, пејоративне, вулгарне, код којих се перцепција увећаног квантитета/ квалитета не испољава на нивоу творбене категорије аугментатива.

\section{Цитирана литература}

Бечева, Ничка. „О дублетности код деминутива и аугментатива у савременом српском језику”. Научни састанак слависта у Вукове дане 29, 1, 2000: 197-203.

[Bečeva, Nička. ,O dubletnosti kod deminutiva i augmentativa u savremenom srpskom jeziku". Naučni sastanak slavista u Vukove dane 29, 1, 2000: 197-203]

Вељковић-Станковић, Драгана. „Деноминални деминутиви и аугментативи значење и творба". Научни састанак слависта у Вукове дане 36, 1, 2007: 387-405.

[Veljković-Stanković, Dragana. „Denominalni deminutivi i augmentativi - značenje i tvorba”. Naučni sastanak slavista u Vukove dane 36, 1, 2007: 387-405]

Јовановић, Владан. Деминутивне и аугментативне именице у српском језику. Београд: Институт за српски језик САНУ, 2010.

[Jovanović, Vladan. Deminutivne i augmentativne imenice u srpskom jeziku. Beograd: Institut za srpski jezik SANU, 2010]

Клајн, Иван. Творба речи у савременом српском језику. Суфиксација и конверзија. Део 2. Београд: Завод за уџбенике и наставна средства, 2003.

[Klajn, Ivan. Tvorba reči u savremenom srpskom jeziku. Sufiksacija i konverzija. Deo 2. Beograd: Zavod za udžbenike i nastavna sredstva, 2003]

Киршова, Маријана. „Аугментативи са суфиксима -ина, -етина, -урина у Вуковом Рјечнику". Наш језик 28, 1-2, 1988: 42-54.

[Kiršova, Marijana. „Augmentativi sa sufiksima -ina, -etina, -urina u Vukovom Rječniku”. Naš jezik 28, 1-2, 1988: 42-54]

Новокмет, Слободан. „Нове речи са суфиксом -ина и његовим варијантама у српском језику". Наш језик 43, 3-4, 2012: 55-68.

[Novokmet, Slobodan. „Nove reči sa sufiksom -ina i njegovim varijantama u srpskom jeziku". Naš jezik 43, 3-4, 2012: 55-68]

Пецо, Асим. „Именице на -ура у нашем језику”. Наш језик 31, 1-5, 1996: 146-162.

[Peco, Asim. „Imenice na -ura u našem jeziku”. Naš jezik 31, 1-5, 1996: 146-162]

Радуловић, Јован. „Аугментативно-пејоративна значења неких именица”. Наш језик 8, 3-4, 1956: 106-113.

[Radulović, Jovan. „Augmentativno-pejorativna značenja nekih imenica”. Naš jezik 8, 3-4, 1956: 106-113]

Стевановић, Михаило. Савремени српскохрватски језик: граматички системи и књижевнојезичка норма. Део 1. Београд: Научно дело, 1964.

[Stevanović, Mihailo. Savremeni srpskohrvatski jezik: gramatički sistemi i književnojezička norma. Deo 1. Beograd: Naučno delo, 1964]

Чампар, Драгован. „Род и број именичких аугментатива у српскохрватском 
језику”. Научни састанак слависта у Вукове дане 13, 1, 1984: 289-301.

[Čampar, Dragovan. „Rod i broj imeničkih augmentativa u srpskohrvatskom jeziku”. Naučni sastanak slavista u Vukove dane 13, 1, 1984: 289-301]

Čermák, František. „Já vůl, ty vole / ty si vůl, to je vůl““. Čeština doma a ve světě 9 , 1-2, 2001: 27-30.

Dokulil, Miloš, Karel Horálek, Jiřina Hůrková (eds.) Mluvnice češtiny I: fonetika, fonologie, morfonologie a morfemika, tvoření slov. Praha: Academia, 1986.

Chlumská, Lucie, Olga Richterová. „Překladová čeština v korpusech“. Naše řeč 97, 4-5, 2014: 259-269.

Karlík, Petr, Marek Nekula, Zdenka Rusínová (eds.) Příruční mluvnice češtiny. Praha: Nakladatelství Lidové noviny, 1996.

Karlík, Petr, Marek Nekula, Jana Pleskalová (eds.) Nový encyklopedický slovník češtiny. Praha: NLN, 2016.

Makišova, Ana. „Imenički augmentativi u slovačkom i srpskom jeziku - građenje i semantika". Славистика 9, 2005: 185-191.

Martinková, Michaela. „K metodologii využití paralelních korpusů v kontrastivní lingvistice“. Naše řeč 97, 4-5, 2014: 270-285.

Nekula, Marek. „Deminutiva a augmentativa v češtině z typologického hlediska“. [In:] A. Bičan, J. Klaška, P. Macurová, J. Zmrzlíková (eds.) Karlík a továrna na lingvistiku. Prof. Petru Karlíkovi k šedesátým narozeninám. Brno: Masarykova univerzita, 2010: 304-316.

Peco, Asim, Živojin, Stanojčić (eds.) Srpskohrvatski jezik. Beograd: Interpres, 1972.

Šimandl, Josef (ed.) Slovník afixů užívaných v češtině. Praha: Karolinum, 2017. $<$ http://www.slovnikafixu.cz> 02.07.2020.

Śtícha, František et al. Velká akademická gramatika spisovné češtiny I. Morfologie: druhy slov, tvoření slov. Část 2. Praha: Academia, 2018.

\section{Извори}

ИА: Андрић, Иво. Омерпаша Латас. Београд: Просвета, 1976.

[Andrić, Ivo. Omerpaša Latas. Beograd: Prosveta, 1976]

ДМ: Михајловић, Драгослав. Кад су цветале тикве. Нови Сад: Матица српска, 1968.

[Mihajlović, Dragoslav. Kad su cvetale tikve. Novi Sad: Matica srpska, 1968]

PCJ: Вујанић, Милица et al. Речник српскога језика. Нови Сад: Матица српска, 2011.

[Vujanić, Milica et al. Rečnik srpskoga jezika. Novi Sad: Matica srpska, 2011]

PMC: Стевановић, Михајло et al. (eds.) Речник српскохрватскога књижевног језика I-VI. Нови Сад: Матица српска, 1967-1976.

[Stevanović, Mihajlo et al. (eds.) Rečnik srpskohrvatskoga književnog jezika I-VI. Novi Sad: Matica srpska, 1967-1976]

ДЋ: Ћосић, Добрица. Време смрти. Београд: Просвета, 1976.

[Ćosić, Dobrica. Vreme smrti. Beograd: Prosveta, 1976]

МЦ: Црњански, Милош. Сеобе. Београд: Просвета, 1966.

[Crnjanski, Miloš. Seobe. Beograd: Prosveta, 1966]

ЧСР: Качаник, Емилија et al. Чешко-српски речник I, II. Београд: САНУ, 2001.

[Kačanik, Emilija et al. Češko-srpski rečnik I, II. Beograd: SANU, 2001]

Andrić, Ivo. Omerpaša Latas. Praha: Melantrich, 1981. Překlad: Jiří Fiedler.

ASSČ: Akademický slovník současné češtiny. Ústav pro jazyk český AV ČR. <http:// 
www.slovnikcestiny.cz/uvod.php>28.06.2020.

MБ: Bulatović, Miodrag. Crveni petao leti ka nebu. Zagreb: Naprijed, 1959.

Bulatović, Miodrag. Červený kohout letí k nebi. Praha: Odeon, 1972. Překlad: Dušan Karpatský.

Crnjanski, Miloš. Běženci panonských bažin. Praha: Odeon, 1981. Překlad: Milada Nedvědová.

Český národní korpus. <https://www.korpus.cz>02.07.2020.

3h: Ćirić, Zoran. Hobo. Beograd: Narodna knjiga Alfa, 2002.

Ćirić, Zoran: Hobo. Praha: Runa, 2012. Překlad: Jan Doležal.

Ćosić, Dobrica. Čas smrti. Praha: Odeon, 1976. Překlad: Milada Nedvědová.

Gerzić, Borivoj. Rečnik srpskog žargona (i žargonu srodnih reči i izraza). Beograd: Bookbridge, 2012.

ДК: Kiš, Danilo. Enciklopedija mrtvih. Beograd: Prosveta, 1990.

Kiš, Danilo. Encyklopedie mrtvých. Praha: Mladá fronta, 1995. Překlad: Milada Nedvědová.

Mihajlović, Dragoslav. Prohra. Praha: Odeon, 1979. Překlad: Jiří Fiedler.

SCHČS: Jeníková, Anna, Karel Lemarie, Jan Sedláček, Stanislava Sýkorová. Srbocharvátsko český slovník. Praha: Academia, 1982.

SNČ: Hugo, Jan, Markéta Fidlerová, Kateřina Adamková, Zdeňka Juránkova (eds.) Slovník nespisovné češtiny. Praha: Maxdorf, 2006.

SSČ: Filipec, Josef, František Daneš, Jaroslav Machač, Vladimír Mejstř́k (eds.) Slovník spisovné češtiny pro školu a veřejnost. Praha: Academia, 1994.

SSJČ: Havránek, Bohuslav, Jaromír Bělič, Miloš Helcl, Alois Jedlička (eds.) Slovník spisovného jazyka českého I-IV. Praha: Československá akademie věd, 1960-1971.

ДВ: Velikić, Dragan. Astragan. Beograd: Duška, 1992.

Velikić, Dragan. Astrachán. Praha: Triada, 1997. Překlad: Ana Adamovičová.

\section{Katarina Mitrićević-Štepanek}

\section{AUGMENTATIVES IN SERBIAN AND CZECH LANGUAGES IN THE CZECH NATIONAL CORPUS}

\section{Summary}

The paper discusses augmentative derivatives in Serbian and Czech, collected from the Czech National Corpus through the Treq application, which includes translation equivalents of Czech and other languages based on data from the InterCorp parallel corpus. Their presence in the corpus is monitored, their semantics and function in Serbian language are analyzed and formal and semantic equivalents in Czech are determined. The lexicographic equivalents are specified and the list of translation equivalents is supplemented.

Augmentatives have a different status in the two given languages, stemming from the peripheral position they have in Czech. Due to this fact, it is concluded that the equivalents are rarely augmentative and mostly either analytical (for example adjective + noun), or words of the colloquial Czech language, as well as pejorative or vulgar words.

Keywords: augmentatives, Serbian language, Czech language, Czech National Corpus, semantics, function, equivalence. 